DOI https://doi.org/10.18551/rjoas.2018-09.29

\title{
COMPARATIVE EFFECTS OF MERGERS AND ACQUISITIONS ON THE COMPANIES' FINANCIAL PERFORMANCE
}

\author{
Yustisia Natali \\ Faculty of Economics and Business, Perbanas Institute, Indonesia \\ E-mail: natali@perbanas.id
}

\begin{abstract}
This study aims to determine the comparative financial performance of companies before and after mergers and acquisitions. Company performance is measured by using financial ratios, namely: current ratio, total asset turnover, debt to equity ratio and net profit margin. While the object of this study include eleven manufacturing companies listed on the Indonesia Stock Exchange (BEI) in the period of 2009-2013 that once conducted mergers and acquisitions. Data analysis method used is quantitative method, using SPSS 21 with the Kolmogorov-Smirnov normality test, Wilcoxon signed rank test and paired sample t-test. Paired sample t-test on CR and DER ratios differ two years and three years before and after merger acquisition and three years before and three years after mergers and acquisitions, while TATO is different two years before and three years after mergers and acquisitions. However, NPM did not differ in all observation periods.
\end{abstract}

\section{KEY WORDS}

Acquisitions, financial performance, mergers, public service.

In the era of globalization and free trade like now, every company is required to continue to develop. This is done so that the company can survive and have competitiveness in carrying out its business objectives. This moment opens a company opportunity to develop itself by taking over or merging a company, or better known as a merger or acquisition (Nugroho, 2010).

According to Gumilarsjah (2016: 4), a merger occurred when two companies agreed to form a joint company, which combined the assets and obligations of the two companies. In the merger, the synergy of the company becomes a benchmark. Synergy generated through a combination of simultaneous activities from strengths or more elements of a company that joins so that the combined activity produce a greater effect than the sum of company activities if they work alone (Brigham and Houston, 2010: 468). While Hindryanto and Retnani (2017) stated that acquisition is the takeover of part or all of the company's assets and shares so that the acquiring company has the power and control rights of the company taken over. The difference is that the acquired company is still standing and not disappearing like a merged company.

On the other hand, one of the factors seen by prospective investors to determine stock investment is by assessing financial performance (Mahendra and Alfredo: 2012). Maintaining and improving financial performance is highly recommended so that stocks continue to always exist and remain attractive to investors. Financial ratios that can be used as a reference to determine whether mergers and acquisitions are feasible are the current ratio (CR), total asset turnover (TATO), debt to equity ratio (DER) and net profit margin (NPM).

Wibowo (2012) analyzes the comparison of the company's financial performance before and after mergers and acquisitions. The results showed that CR, TATO and NPM had no significant effect a year before and three years after mergers and acquisitions were made. While DER did not experience significant changes.

Then Kharisma (2014) analyzed the comparison of the company's financial performance before and after the mergers and acquisitions of acquiring companies listed on the Indonesia Stock Exchange. The results show that NPM, DER and CR have a significant effect for three years before and two years after mergers and acquisitions. 
In addition, Aprilia and Oetomo (2015) examined the comparison of financial performance before and after the acquisition of manufacturing companies. Their research concluded that CR, TATO and NPM had a significant effect after the acquisition, so the company did the right thing. However, DER shows no effect after the acquisition.

Based on data from www. sahamok.com as of January 3, 2015, the number of publicly listed companies listed on the IDX was 507 companies with nine core businesses. Among these companies, manufacturing companies' developed well so that they were often used as objects of research regarding their business activities, such as mergers or acquisitions.

Referring to various differences in conclusions from previous studies, researchers are interested in conducting further scientific studies on company performance before and after mergers and acquisitions. The general purpose of this study is to compare the effects of mergers and acquisitions on the manufacturing companies' financial performance before and after the corporate action.

The observation period studied was one year before one year after; one year before two years after; two years before two years after; two years before three years after and three years before three years after the company took corporate actions of mergers and acquisitions. While the financial performance measured is the current ratio, total asset turnover, debt to equity ratio and net profit margin. The results of this study are also expected to be used as additional references for other researchers who will conduct research in the same scope.

\section{THEORETICAL REVIEW}

Sartono (2001: 365) argues that a merger is a combination of two or more companies that merge into a new company. In a merger, companies that have more assets and greater profit levels will still be left standing, while companies with smaller sizes will be dissolved. Furthermore, Noer (2009: 242) states that a merger is the merger of two or more companies into one new company. This means from some of these definitions it can be concluded that the merger is the process of merging two companies, one of them remains standing under the name of the company, while the other is lost with all its names and wealth.

Moin (2010: 6) reveals that parties who are still alive or accepting a merger are called surviving firms or issuing firms. Meanwhile, the company that stopped and disbanded after the merger was called a merged firm. Company A by itself has an increasingly large size because all assets and liabilities of company B are transferred to the company A. Company $B$ will abandon its legal status as a separate entity and after the merger its status changes to part (business unit) under company A. Thus, company B cannot act lawfully in its own name because company A has become a public company that sells its shares in the Indonesian capital market.

The explanation can be described as a scheme for mergers as one of the company's strategies.

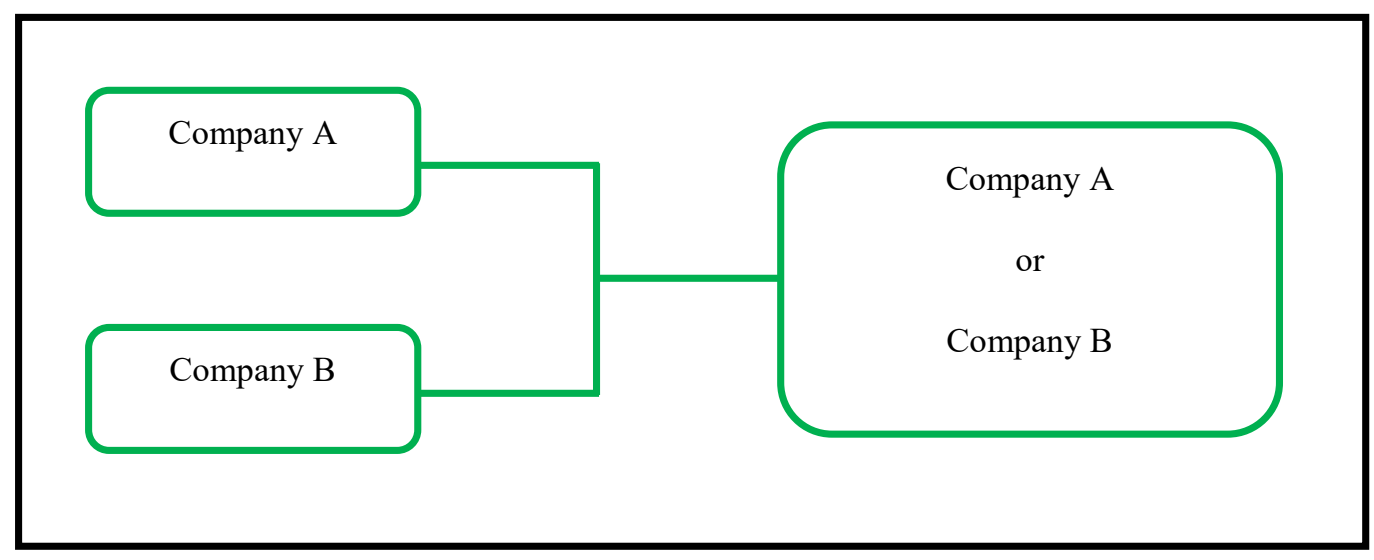

Figure 1 - Merger Scheme (Source: Moin, 2010:7) 
Meanwhile acquisition comes from the word acquisition which means buying or getting something to add to objects that have been previously owned. In business terminology, acquisitions can also be interpreted as taking ownership or control over shares or being taken over while remaining as separate legal material (Moin, 2010: 8).

Switching control means that the acquirer has a majority of voting stock, which is usually indicated by the ownership of more than 50 percent of the voting rights. It is possible that even if the shares have less than that amount, company A can also be declared as the majority owner if B's articles of association mention such things. However, it is also possible that the owner of 51 percent is not necessarily stated as the owner of majority votes if in the articles of association of company A mention otherwise. The acquisition raises the relationship between companies (acquirers) and subsidiaries (acquired) (Moin, 2010: 8).

From this explanation it can be described as a process of one form of acquisition.

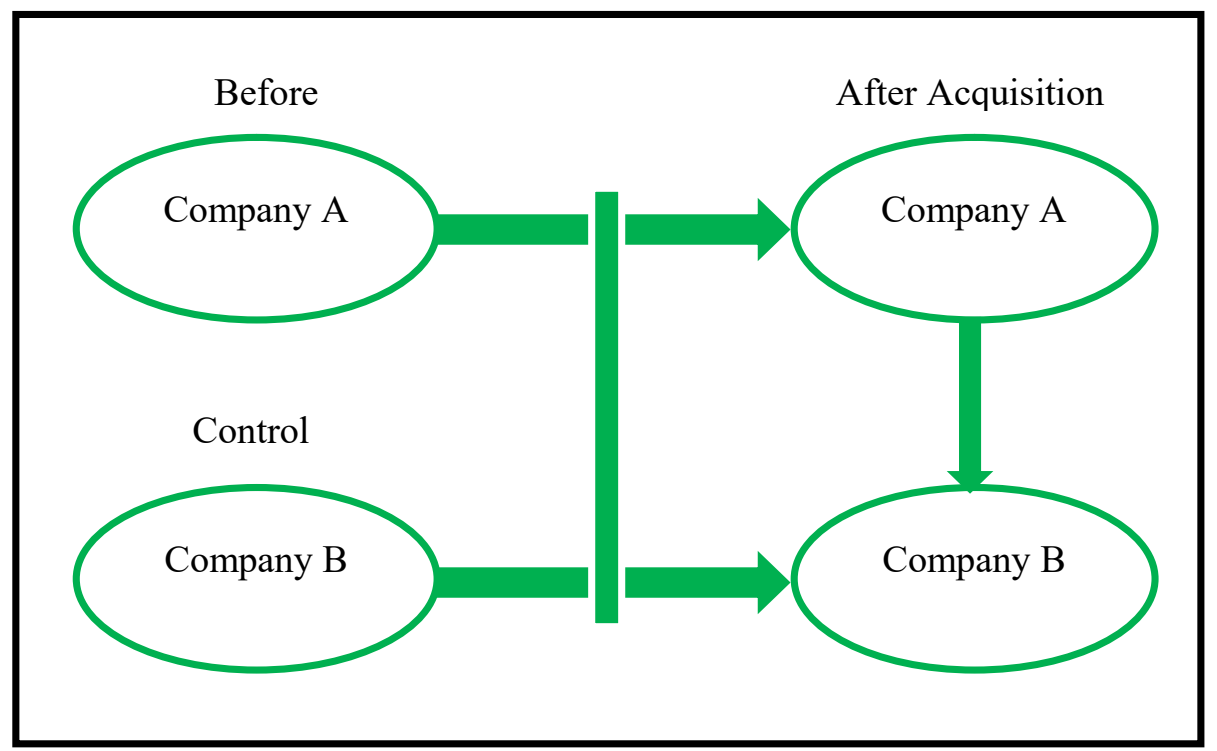

Figure 2 - Acquisition Scheme (Source: Moin, 2010:9)

Financial ratio analysis is a general method used to measure company performance. Ratio is a tool that compares things to other things so that it can show the relationship or correlation of a financial report in the form of balance sheet and income statement. The types of ratios used in this study are liquidity ratios, activity ratios, solvency ratios, and profitability ratios (Simamora, 2000: 822).

Current Ratio (CR) provides information about the ability of current assets to cover current debt. The greater the comparison of current assets with current debt, the higher the ability of the company to cover its short-term liabilities. So it is said to be healthy if the CR is above 1 or 100 percent. This means that current assets must be far above the amount of current debt (Harahap, 2002: 301).

$$
\text { Current Ratio }=\frac{\text { Current Asset }}{\text { Current Liability }}
$$

Total Assets Turnover (TATO) measures the extent to which a company's ability to generate sales is based on the total assets held. The higher this ratio means the more effective the proportion of these assets (Hanafi and Halim, 2000: 81). TATO can be calculated by the following formula:

$$
\text { TATO }=\frac{\text { Sales }}{\text { Total Asset }}
$$


Debt to equity ratio is a balance between debt owned by a company and its own capital. The higher this ratio means less capital than the debt. The smaller this ratio the better (Harahap, 2002: 304), with the following formula:

$$
\text { DER }=\frac{\text { Total Debt }}{\text { Total Equity }}
$$

Net profit margins are used to measure the amount of net income generated by every single Rupiah of sales and measure all efficiency, both production, administration, marketing, funding and tax management. If the ratio is low, the sales are too low for a certain level of costs, or the costs are too high for a certain level of sales, or a combination of the two things (Prastowo and Juliaty, 2003: 91). This ratio can be calculated by the formula:

$$
\mathrm{NPM}=\frac{\text { Earning After Tax }}{\text { Net Sales }}
$$

Here are some studies that are used as comparisons. Nugroho's research (2010) entitled "Comparative Analysis of Corporate Financial Performance Before and After Mergers and Acquisitions". This study uses the Wilcoxon Signed Rank Test. The results obtained in the test one year before with one year after showing NPM, DER, TATO, and CR there were no significant differences. As for one year before two years after, only DER experienced a significant difference. Furthermore, for one year before with four years after proving the same results, there were no significant differences from all variables studied.

Hamidah and Noviani (2013) in their research entitled "Comparative Analysis of Financial Performance Before and After Acquisition" obtained CR results have increased. This study uses paired sample $t$ test.

Different research results were obtained in Ahmed's (2014) study, entitled "Effect of Merger and Acquisition on Pakistan's Financial Performance of Manufacturing Companies". The variables used are CR proving that there is no significant difference but DER is positively significant different.

Kharisma (2014) examined about "Comparative Analysis of Corporate Financial Performance Before After Merger and Acquisition". The result was that CR and TATO did not experience significant differences, but DER and NPM were increased. Furthermore, Aprilia and Oetomo (2015) research on "Comparison of Financial Performance Before and After Acquisition in Manufacturing Companies". The conclusion of this study is CR, TATO, and NPM significant positive, while DER is not significant.

\section{METHODS OF RESEARCH}

This type of research is hypothesis testing. Dantes (2012: 164) states that hypotheses are presumptions or assumptions that must be tested through data or facts obtained from research in order to guide researchers in exploring the desired data. This study will examine the effect of independent variables on the dependent variable. The unit of analysis uses several financial ratios which include: current ratio, total asset turnover, debt to equity ratio, and net profit margin. The scope of this research is manufacturing companies that conduct mergers and acquisitions on the IDX during the period 2009-2013.

The population in this study is all manufacturing companies in the mining and property sectors listed on the Indonesia Stock Exchange (IDX).

This study uses purposive sampling technique. The company is chosen based on certain criteria in order to get a representative sample.

The criteria are as follows:

- Manufacturing companies listed on the Indonesia Stock Exchange that conduct mergers and acquisitions during 2009-2013;

- The company takes ownership of another company in the form of share ownership of more than 50 percent of the shares; 
- The company during the study period routinely published financial statements as of December 31 in full;

- Companies that report the date of announcement of mergers and acquisitions during the period 2009-2013.

Given the large number of samples in this study, it is illustrated in the table of the sample selection process which can be seen in the appendix. The following is a list of companies that are included in the research sample consisting of 11 companies.

Table 1 - Sample Selection

\begin{tabular}{|c|c|c|c|c|}
\hline No & Company & Industrial Sector & Date of Mergers \& Acquisitions & Gloss \\
\hline 1 & PT.Indika Energi,Tbk & Mining & June 30, 2009 & Merger \\
\hline 2 & PT.Akra Corporindo,Tbk & Mining & November 11, 2009 & Merger \\
\hline 3 & PT.Indonesia Prima,Tbk & Property & December 2, 2010 & Acquisition \\
\hline 4 & PT.Astra Internasina,Tbk & Automotive & December 27, 2010 & Merger \\
\hline 5 & PT.Aneka Tambang,Tbk & Mining & May 18, 2011 & Merger \\
\hline 6 & PT.Agung Podomoro.Tbk & Property & November 17, 2011 & Acquisition \\
\hline 7 & PT.Berau Coal Energ,Tbk & Mining & July 20, 2011 & Acquisition \\
\hline 8 & PT.Kalbe Farma.Tbk & Pharmacy & August 3, 2012 & Merger \\
\hline 9 & PT.Alam Sutra Real,Tbk & Property & August 28, 2012 & Acquisition \\
\hline 10 & PT.Harum Energi.Tbk & Mining & July 2, 2013 & Acquisition \\
\hline 11 & PT.Medco Internasional, Tbk & Mining & January 11, 2013 & Acquisition \\
\hline
\end{tabular}

Source: www.sahamok.com accessed March 28, 2017.

Data processing of this study uses the help of SPSS version 21 for windows. Before being tested, the Kolmogorov-smirnov data normality test is first tested to see whether the data is normally distributed or not. If the significant value is more than 0.05 , the data is normally distributed, but if the significance value is less than 0.05 , the data is not normally distributed. If the data is normally distributed, hypothesis testing uses a paired sample t-test. However, if the data is not normally distributed, then the data test will be ranked with the Wilcoxon signed rank test.

\section{RESULTS AND DISCUSSION}

Based on the results of the normality test for the sample of this study, it can be concluded that all data are normally distributed. Therefore, the next test uses a paired sample t-test.

Table 2 - Paired Sample T-test, One Year Before Compared to One Year After

\begin{tabular}{|c|c|c|c|c|c|c|c|c|c|}
\hline & & \multicolumn{5}{|c|}{ Paired Differences } & \multirow[b]{3}{*}{$\mathrm{t}$} & \multirow[b]{3}{*}{ df } & \multirow[b]{3}{*}{ Sig. (2-tailed) } \\
\hline & & \multirow[b]{2}{*}{ Mean } & \multirow[b]{2}{*}{ Std. Deviation } & \multirow{2}{*}{$\begin{array}{l}\text { Std. Error } \\
\text { Mean }\end{array}$} & \multicolumn{2}{|c|}{$\begin{array}{l}\text { 95\% Confidence Interval of the } \\
\text { Difference }\end{array}$} & & & \\
\hline & & & & & Lower & Upper & & & \\
\hline Pair 1 & CR_SBLM - CR_SUDH & 3.95636 & 57.51583 & 17.34167 & -34.68330 & 42.59602 & .228 & 10 & .824 \\
\hline Pair 2 & $\begin{array}{l}\text { TATO_SBLM - } \\
\text { TATO_SUDH }\end{array}$ & 15.27182 & 45.74845 & 13.79368 & -15.46241 & 46.00604 & 1.107 & 10 & .294 \\
\hline Pair 3 & $\begin{array}{l}\text { DER_SBLM - } \\
\text { DER_SUDH }\end{array}$ & -34.91636 & 121.78565 & 36.71976 & -116.73308 & 46.90035 & -.951 & 10 & .364 \\
\hline Pair 4 & $\begin{array}{l}\text { NPM_SBLM - } \\
\text { NPM_SUDH }\end{array}$ & 31.17455 & 82.08108 & 24.74838 & -23.96827 & 86.31736 & 1.260 & 10 & .236 \\
\hline
\end{tabular}

Source: Data Processed (2018).

Based on table 2, the results of paired sample t-tests can be stated as follows:

The probability value of $\mathrm{CR}(0.824)>$ alpha $(0.05)$, then $\mathrm{H}_{0}$ is accepted and $\mathrm{Ha}$ is rejected. This means that $\mathrm{CR}$ by comparing the performance of one year before one year after not having a significant effect. 
The probability value variable TATO (0.294)> alpha (0.05), then $\mathrm{H}_{0}$ is accepted and $\mathrm{Ha}$ is rejected. This means TATO by comparing the financial performance of a company one year wbefore one year after no differences occur.

Probability value of DER variable (0.364)> alpha (0.05), it means that $H_{0}$ is accepted while $\mathrm{Ha}$ is rejected. Thus DER after comparing financial performance one year before with one year after not having a significant effect.

The probability value variable NPM (0.236)> alpha (0.05), then $\mathrm{H}_{0}$ is accepted while $\mathrm{Ha}$ is rejected. That is, there is no difference in NPM after comparing one year before and one year after.

Table 3 - Paired Sample T-test, One Year Before Compared to Two Years After

\begin{tabular}{|c|c|c|c|c|c|c|c|c|c|}
\hline & & \multicolumn{5}{|c|}{ Paired Differences } & \multirow[b]{3}{*}{$t$} & \multirow[b]{3}{*}{$d f$} & \multirow[b]{3}{*}{ Sig. (2-tailed) } \\
\hline & & \multirow[b]{2}{*}{ Mean } & \multirow[b]{2}{*}{ Std. Deviation } & \multirow{2}{*}{$\begin{array}{l}\text { Std. Error } \\
\text { Mean }\end{array}$} & \multicolumn{2}{|c|}{$\begin{array}{l}\text { 95\% Confidence Interval of the } \\
\text { Difference }\end{array}$} & & & \\
\hline & & & & & Lower & Upper & & & \\
\hline Pair 1 & CR_SBLM - CR_SUDH & -.19545 & 1.11669 & .33669 & -.94565 & .55475 & -.581 & 10 & .574 \\
\hline Pair 2 & TATO_SBLIM - TATO_SUDH & .18636 & .44925 & .13545 & -.11545 & .48817 & 1.376 & 10 & .199 \\
\hline Pair 3 & DER_SBLM - DER_SUDH & -1.15273 & 3.58157 & 1.07988 & -3.55886 & 1.25340 & -1.067 & 10 & .311 \\
\hline Pair 4 & NPM_SBLM - NPM_SUDH & .01545 & .11103 & .03348 & -.05914 & .09004 & .462 & 10 & .654 \\
\hline
\end{tabular}

Source: Data Processed (2018).

Based on table 3, the results of paired sample t-tests can be stated as follows:

The probability value of the variable $C R(0.574)>$ alpha $(0.05)$, then $H_{0}$ is accepted while $\mathrm{Ha}$ is rejected. This means that $\mathrm{CR}$ has no significant effect after mergers and acquisitions have been made.

Based on the probability of variable TATO (0.199)> alpha (0.05), then $\mathrm{H}_{0}$ is accepted with Ha rejected. That is, TATO has no significant difference after the merger and acquisition process.

The probability of the DER variable (0.311)> alpha (0.05), then $\mathrm{H}_{0}$ is accepted while $\mathrm{Ha}$ is rejected. Therefore, after comparing the performance one year before with one year after, DER has no significant effect.

The probability value variable NPM (0.654)> alpha (0.05), then $\mathrm{H}_{0}$ is accepted and $\mathrm{Ha}$ is rejected. This means that after the merger and acquisition there is no synergy that can be expected for NPMs.

Table 4 - Paired Sample T-test, Two Years Before Compared to Two Years After

\begin{tabular}{|c|c|c|c|c|c|c|c|c|c|}
\hline & \multicolumn{5}{|c|}{ Paired Differences } & \multirow[b]{3}{*}{$t$} & \multirow[b]{3}{*}{ df } & \multirow[b]{3}{*}{ Sig. (2-tailed) } \\
\hline & & \multirow[b]{2}{*}{ Mean } & \multirow[b]{2}{*}{ Std. Deviation } & \multirow{2}{*}{$\begin{array}{l}\text { Std. Error } \\
\text { Mean }\end{array}$} & \multicolumn{2}{|c|}{$\begin{array}{l}\text { 95\% Confidence Interval of the } \\
\text { Difference }\end{array}$} & & & \\
\hline & & & & & Lower & Upper & & & \\
\hline Pair 1 & CR_SBLM - CR_SUDH & -4.15818 & 58.63031 & 17.67770 & -43.54656 & 35.23020 & -.235 & 10 & .819 \\
\hline Pair 2 & TATO_SBLM - TATO_SUDH & -8.15000 & 61.24774 & 18.46689 & -49.29679 & 32.99679 & -.441 & 10 & .668 \\
\hline Pair 3 & DER_SBLM - DER_SUDH & -19.08091 & 81.37624 & 24.53586 & -73.75021 & 35.58839 & -.778 & 10 & .455 \\
\hline Pair 4 & NPM_SBLM - NPM_SUDH & -18.28545 & 78.70848 & 23.73150 & -71.16253 & 34.59162 & -.771 & 10 & .459 \\
\hline
\end{tabular}

Source: Data Proccessed (2018).

Based on table 4, the results can be stated as follows:

The probability value of variable CR (0.819)> alpha (0.05), then $\mathrm{H}_{0}$ is accepted and $\mathrm{Ha}$ is rejected. This means that $\mathrm{CR}$ has no significant effect in two years before and two years after mergers and acquisitions.

The probability value of variable TATO (0.668)> alpha (0.05), then $\mathrm{H}_{0}$ is accepted while $\mathrm{Ha}$ is rejected. This means that TATO is no different from before.

The probability value of the variable DER (0.455)> alpha (0.05). Thus there is no significant difference in DER two years before and two years after mergers and acquisitions. 
The probability value of variable NPM (0.459)> alpha (0.05), then $\mathrm{H}_{0}$ is accepted while $\mathrm{Ha}$ is rejected. That is, the NPM has no significant effect after the merger and acquisition in two years before and two years after.

Table 5 - Paired Sample T-test, Two Years Before Compared to Three Years After

\begin{tabular}{|c|c|c|c|c|c|c|c|c|c|}
\hline & \multicolumn{5}{|c|}{ Paired Differences } & \multirow[b]{3}{*}{$t$} & \multirow[b]{3}{*}{ df } & \multirow[b]{3}{*}{ Sig. (2-tailed) } \\
\hline & & \multirow[b]{2}{*}{ Mean } & \multirow[b]{2}{*}{ Std. Deviation } & \multirow{2}{*}{$\begin{array}{c}\text { Std. Error } \\
\text { Mean }\end{array}$} & \multicolumn{2}{|c|}{$\begin{array}{l}95 \% \text { Confidence Interval of the } \\
\text { Difference }\end{array}$} & & & \\
\hline & & & & & Lower & Upper & & & \\
\hline Pair 1 & CR_SBLM - CR_SUDH & -31000 & .35154 & .10599 & -.54617 & -.07383 & -2.925 & 10 & .015 \\
\hline Pair 2 & TATO_SBLM - TATO_SUDH & 12091 & 17137 & .05167 & .00578 & .23604 & 2.340 & 10 & .041 \\
\hline Pair 3 & DER_SBLM - DER_SUDH & .31818 & .47182 & 14226 & . 00121 & .63516 & 2.237 & 10 & .049 \\
\hline Pair 4 & NPM_SBLM - NPM_SUDH & -.02636 & .28430 & .08572 & -.21736 & .16463 & -308 & 10 & .765 \\
\hline
\end{tabular}

Source: Data Processed (2018).

Based on table 5, the results of paired sample t-tests can be stated as follows:

Probability value of variable CR $(0.015)<$ alpha $(0.05)$, then $\mathrm{H}_{0}$ is rejected while $\mathrm{Ha}$ is accepted. That is, there are significant differences in CR two years before with three years after mergers and acquisitions.

Variable probability value of TATO $(0.041)<$ alpha $(0.05)$, then $\mathrm{H}_{0}$ is rejected and $\mathrm{Ha}$ is accepted. This means a significant difference in TATO two years before with three years after mergers and acquisitions.

Probability value of DER variable $(0.049)<$ alpha $(0.05)$, then $\mathrm{H}_{0}$ is rejected and $\mathrm{Ha}$ is accepted. Thus, there are significant differences in DER two years before with three years after mergers and acquisitions.

The probability value of variable NPM (0.765)> alpha (0.05) indicates that $H_{0}$ is accepted while Ha is rejected. This means that there is no difference in NPM or there is no synergy from mergers and acquisitions.

Table 6 - Paired Sample T-test, Three Years Before Compared to Three Years After

\begin{tabular}{|c|c|c|c|c|c|c|c|c|c|}
\hline & & \multicolumn{5}{|c|}{ Paired Differences } & \multirow[b]{3}{*}{$t$} & \multirow[b]{3}{*}{ df } & \multirow[b]{3}{*}{ Sig. (2-tailed) } \\
\hline & & \multirow[b]{2}{*}{ Mean } & \multirow[b]{2}{*}{ Std. Deviation } & \multirow{2}{*}{$\begin{array}{c}\text { Std. Error } \\
\text { Mean }\end{array}$} & \multicolumn{2}{|c|}{$\begin{array}{l}\text { 95\% Confidence Interval of the } \\
\text { Difference }\end{array}$} & & & \\
\hline & & & & & Lower & Upper & & & \\
\hline Pair 1 & CR_SBLM - CR_SUDH & -.14909 & .76181 & .22969 & -.66088 & .36270 & -.649 & 10 & .531 \\
\hline Pair 2 & $\begin{array}{l}\text { TATO_SBLM - } \\
\text { TATO_SUDH }\end{array}$ & -.64364 & .80088 & .24147 & -1.18167 & -.10560 & -2.665 & 10 & .024 \\
\hline Pair 3 & $\begin{array}{l}\text { DER_SBLM - } \\
\text { DER_SUDH }\end{array}$ & -.16909 & .61588 & .18570 & -.58285 & .24466 & -.911 & 10 & .384 \\
\hline Pair 4 & $\begin{array}{l}\text { NPM_SBLM- } \\
\text { NPM_SUDH }\end{array}$ & .04818 & .13695 & .04129 & -.04383 & .14019 & 1.167 & 10 & .270 \\
\hline
\end{tabular}

Source: Data Processed (2018).

Based on table 6 , the results of paired sample t-tests can be stated as follows:

The probability value of the variable CR (0.531)> alpha (0.05), then $\mathrm{H}_{0}$ is accepted while $\mathrm{Ha}$ is rejected. This means that there is no significant difference in $\mathrm{CR}$.

Variable probability value of TATO $(0.024)<$ alpha $(0.05)$, then $\mathrm{H}_{0}$ is rejected and $\mathrm{Ha}$ is accepted. Thus, there is a significant difference between TATO three years before with three years after mergers and acquisitions.

The probability value of the DER variable $(0.384)>$ alpha $(0.05)$, then $H_{0}$ is accepted and $\mathrm{Ha}$ is rejected. This means there is no significant difference in DER.

The probability value of variable NPM $(0.270)>$ alpha $(0.05)$ indicates that $\mathrm{H}_{0}$ is accepted while $\mathrm{Ha}$ is rejected. That is, there is no difference in NPM or there is no synergy obtained from mergers and acquisitions. 


\section{DISCUSSION OF RESULTS}

Based on the tests that have been carried out, CR is significantly different in two years before with three years after mergers and acquisitions. Means, Ha is accepted for a period of two years before and three years after. The results of this study support Kharisma (2014) which states that there is a significant increase in current ratio after carrying out mergers and acquisitions. This means that there is an efficiency of the company in managing finances to fulfill its obligations.

Furthermore, based on the same test, TATO differed significantly in the two years prior to three years after mergers and acquisitions. This means that $\mathrm{Ha}$ is accepted for a period of two years before and three years after and three years before with three years after mergers and acquisitions. This research is in line with what was done by Aprilia and Oetomo (2015), which concluded that there were significant differences in total asset turnover after carrying out mergers and acquisitions. According to Moin (2010: 143), if this ratio is high, there is a possibility that companies will use assets above capacity so that companies can increase revenues, for example by increasing sales volume. The greater the TATO ratio shows good management or the level of effectiveness of the company in using all assets to create sales.

Then, based on the results of data processing, DER differs significantly in the two-year period before and three years after mergers and acquisitions. In conclusion, $\mathrm{Ha}$ is accepted while $\mathrm{H}_{0}$ is rejected. This research is not in line with what was done by Aprilia and Oetomo (2015) which stated that DER did not experience differences in periods before and after mergers and acquisitions.

Finally, based on test results, NPM did not differ significantly in the two-year period before with three years after mergers and acquisitions. The conclusion Ha was rejected while $\mathrm{H}_{0}$ was accepted. This result is not in line with research conducted by Aprilia and Oetomo (2015). However, it supports the research conducted by Kharisma (2014) that there is no significant difference in the two years before with three years after mergers and acquisitions. For more details, the following table 7 is a recapitulation of the results of processing with a paired sample t-test.

Table 7 - Interpretation Results of Paired Sample T-test

\begin{tabular}{|c|c|c|c|c|c|c|}
\hline \multirow{2}{*}{ VAR } & \multirow{2}{*}{ YEAR } & \multicolumn{5}{|c|}{ INTERPRETATION RESULTS } \\
\cline { 3 - 7 } & & 1 & 2 & 2 & 3 & 3 \\
\hline CR & 1 & no different & no different & no different & different $^{*}$ & no different \\
\hline TATO & 1 & no different & no different & no different & different $^{*}$ & different $^{*}$ \\
\hline DER & 2 & no different & no different & no different & different $^{*}$ & no different \\
\hline NPM & 3 & no different & no different & no different & no different & no different \\
\hline
\end{tabular}

Source: Researcher (2018).

Based on table 8, the significant results of CR two years before with three years after mergers and acquisitions amounted to 0.015 so that $\mathrm{H}_{0}$ was rejected or there were differences before and after mergers and acquisitions.

Table 8 - Comparison Results of Current Ratio

\begin{tabular}{|c|c|c|c|}
\hline No & CR & Significant & Results \\
\hline 1 & 1 year (-) vs 1 year (+) & 0.824 & No Different \\
\hline 2 & 1 year (-) vs 2 years (+) & 0.574 & No Different \\
\hline 3 & 2 years (-) vs 2 years (+) & 0.819 & Different \\
\hline 4 & 2 years (-) vs 3 years (+) & 0.015 & Different \\
\hline 5 & 3 years (-) vs 3 years (+) & 0.531 & Different \\
\hline
\end{tabular}

Source: Researcher (2018).

This means that companies conducting mergers and acquisitions show good prospects because there is an increase in CR for some companies in the two-year period before with three years after mergers and acquisitions. The results of this study support the 
previous research conducted by Kharisma (2014), that there is an improved outlook for the variable liquidity. But contrary to the results found by Nugroho (2010), that there is no synergy that occurs even said there are no good prospects after mergers and acquisitions have been made.

From table 9, it can be seen that the probability of TATO in two years before compared with three years after the merger is 0.041 then $\mathrm{H}_{0}$ is rejected. That is, there is an improved prospect because there is a slight increase in TATO in several companies after mergers and acquisitions in the two-year period before with three years after mergers and acquisitions. Similarly, TATO three years before with three years after mergers and acquisitions shows a difference because of the significant amount of 0.024 .

This study supports the previous findings of Aprilia and Oetomo (2015) with the result that there are improved prospects for mergers and acquisitions. But different from Kharisma's research (2014) which concluded that there were no synergies that occurred in the two-year period before and three years after mergers and acquisitions. This means that there are no improved prospects for the merger and acquisition.

Table 9 - Comparison Results of Total Aset Turnover

\begin{tabular}{|c|c|c|c|}
\hline No & TATO & Significant & Results \\
\hline 1 & 1 year (-) vs 1 year (+) & 0.294 & No Different \\
\hline 2 & 1 year (-) vs 2 years (+) & 0.199 & No Different \\
\hline 3 & 2 years (-) vs 2 years (+) & 0.668 & Different \\
\hline 4 & 2 years (-) vs 3 years (+) & 0.041 & Different \\
\hline 5 & 3 years (-) vs 3 years (+) & 0.024 & \\
\hline
\end{tabular}

Source: Researcher (2018).

Based on table 10, the significance of DER in two years before and three years after is 0.049 , so $\mathrm{H}_{0}$ is rejected. That is, the company's DER in two years before was different from DER in three years after mergers and acquisitions. The DER value in the company does not seem to improve because after the merger shows the ratio is too high, which indicates that the company uses more loan capital (debt) than using its own capital.

The results of this study support Setiawan's (2013) research which shows significant before and after mergers and acquisitions. However, it is not in line with Ahmed (2014) which proves that there was no synergy in that period.

Table 10 - Comparison Results of Debt to Equity Ratio

\begin{tabular}{|c|c|c|c|}
\hline No & DER & Significant & Results \\
\hline 1 & 1 year (-) vs 1 year (+) & 0.364 & No Different \\
\hline 2 & 1 year (-) vs 2 years (+) & 0.311 & No Different \\
\hline 3 & 2 years (-) vs 2 years (+) & 0.455 & Different \\
\hline 4 & 2 years (-) vs 3 years (+) & 0.049 & No Different \\
\hline 5 & 3 years (-) vs 3 years (+) & 0.270 & \\
\hline
\end{tabular}

Source: Researcher (2018).

Table 11 - Comparison Results of Net Profit Margin

\begin{tabular}{|c|c|c|c|}
\hline No & NPM & Significant & Results \\
\hline 1 & 1 year (-) vs 1 year (+) & 0.236 & No Different \\
\hline 2 & 1 year (-) vs 2 years (+) & 0.654 & No Different \\
\hline 3 & 2 years (-) vs 2 years (+) & 0.459 & No Different \\
\hline 4 & 2 years (-) vs 3 years (+) & 0.765 & No Different \\
\hline 5 & 3 years (-) vs 3 years (+) & 0.270 & \\
\hline
\end{tabular}

Source: Researcher (2018).

Based on table 11, it can be seen that the results of paired sample t-test on the NPM variable for one year before and one year after, one year before and two years after, two years before and two years after and two years before and three years after and three years 
before and three years after the merger and acquisition there is no difference. That is, there are no good prospects for the company in these periods. This research is not in line with Hamidah and Noviani (2013) which states that there are differences that occur in CR, TATO, DER and NPM of the company before and after the merger.

\section{CONCLUSION AND SUGGESTIONS}

Based on the results of the research obtained through the paired sample t-test during the research time window before and after the mergers and acquisitions, it can be concluded that the Current Ratio is different in the two years before compared to three years after the mergers and acquisitions because $\mathrm{CR}$ several companies have increased. Total asset turnover in the two-year period before was different compared to three years after mergers and acquisitions and three years before with three years after mergers and acquisitions also showed an increase.

Similarly, the debt to equity ratio in the two-year period before compared to three years after mergers and acquisitions experienced differences. However, there is no difference in net profit margin in all observation periods.

The recommendations that can be given for the development of further research, namely using the object of research in different corporate sectors (other than manufacturing), such as the textile industry, automotive and banking industry, so as to get more varied results. Furthermore, the observation period is suggested to use a comparison of financial performance in a longer period of time, for example two years before and four years after, two years before and five years after and one year before and five years after mergers and acquisitions. This allows better research findings.

Then, the variables tested are advised not only to use only four financial ratios, because there are many other financial ratios that may have an impact on this corporate action. These ratios include return on equity, return on assets, debt ratio, price earnings ratio and fixed assets turnover.

\section{REFERENCES}

1. Ahmed, M. a. (2014). "Merger and Acquisition: Effect on Financial Performance of Manufacturing Companies of Pakistan". Scientific Research (4), 21.

2. Aprilia dan Oetomo. (2015). "Perbandingan Kinerja Keuangan Sebelum dan Sesudah Akuisisi pada Perusahaan Manufaktur". Jurnal IImu \& Riset Manajemen, Volume 4 Nomer 12, 4-12.

3. Brigham dan Houston. (2010). Dasar-dasar Manajemen Keuangan. Edisi Sepuluh. Buku 2. Jakarta: Salemba Empat.

4. Dantes, N. (2012). Metode Penelitian. Yogyakarta: CV. Andi Offset.

5. Gumilarsjah. (2016). Tahapan Proses Merger dan Akuisisi - M\&A. Jakarta: PPM.

6. Hamidah dan Noviani. (2013). "Perbandingan Kinerja Keuangan Sebelum dan Sesudah Merger dan Akuisisi". Jurnal Riset Manajemen Sains Indonesia, 31-52.

7. Hanafi, M. dan A. Halim. (2000). Analisis Laporan Keuangan. Edisi 1. Cetakan 2. Yogyakarta: AMP-YKPN.

8. Harahap, S. S. (2002). Analisa Kritis atas Laporan Keuangan. Jakarta: PT. Raja Grfindo Persada.

9. Hindryanto dan Retnani. (2017). "Analisis Kinerja Keuangan pada Perusahaan yang Melakukan Akuisisi". Jurnal IImu dan Riset Akuntansi. Volume 6, Nomor 1. Surabaya: STIESIA.

10. Kharisma. (2014). "Analisis Perbandingan Kinerja Keuangan". Jurnal Ekonomi, 13.

11. Mahendra dan Alfredo. (2012). "Pengaruh Kinerja terhadap Nilai Perusahaan Pada Perusahaan Manufaktur di Bursa Efek Indonesia". Jurnal Manajemen, Strategi Bisnis \& Kewirausahaan, 130.

12. Moin, Abdul. (2010). Merger, Akuisisi dan Divestasi. Edisi Kedua. Yogyakarta: Ekonisia.

13. Noer. (2009). Management Event. Bandung: ALFABETA. 
14. Nugroho, M. A. (2010). "Analisis Perbandingan Kinerja Keuangan Sebelum dan Sesudah Merger dan Akuisisi". Jurnal Manajemen, 130.

15. Prastowo, Dwi dan Julaity, Rifka. (2003). Analisis Laporan Keuangan Konsep dan Aplikasi. Yogyakarta: Unit Penerbit \& Percetakan AMP-YKPN.

16. Sartono. (2001). Manajemen Keuangan Teori dan Aplikasi. Yogyakarta: BPEF YOGYAKARTA.

17. Setiawan, Irwan Amdani. (2013). "Analisis Rasio Keuangan untuk Mengukur Kinerja Keuangan Indocement Tunggal Prakarsa Tbk Sebelum dan Sesudah Akuisisi Periode 2007-2011". Jurnal Administrasi Bisnis, Vol.2, No.1: 74-83.

18. Simamora, H. (2000). Akuntansi Basis Pengambilan Keputusan Bisnis. Jakarta : Salemba Empat.

19. Wibowo, F. A. (2012). "Analisis Perbandingan Kinerja Keuangan". Jurnal Akuntansi dan Manajemen, 12-15. 